\title{
The Implementation of Restorative Justice in Resolving Violence on Women and Children as a form of Right of Origin in West Sumatera
}

\author{
Efren Nova ${ }^{1}$, Yoserwan Hamzah ${ }^{2}$ \\ \{efrennova@law.unand.ac.id ${ }^{1}$,yoserwan@law.unand.ac.id\} \\ Criminal Law Department, Faculty of Law, Andalas University Padang, Indonesia
}

\begin{abstract}
Restorative Justice opens up a new awareness about accomplishing problems between sides in criminal matters not only with revenge spirit but with a peaceful way by discussion so both sides can have an advantage based on a collective decision that has been agreed together and to create a balance between the perpetrator and the victim. Indonesia consists of many ethnic groups, custom, and culture. Those things create different sects or groups known as the community of custom law that binds by their customs laws. This research goal is to dig the value of custom law that can be the policy foundation to optimize woman and children protection from abusive acts through the application of Restorative Justice. Based on research results in 7 ( seven) ) nagari in West Sumatera shows that Restorative Justice applied for light crime in 7 ( seven ) Nagari because Restorative Justice is in the same way with Minangkabau's custom law. In settling abusive acts to woman and children, done with a family-based discussion of bajanjang naiak batanggo turun, starts from mamak tungganai, mamak dalam suku, ninik nan barampek, ninik nan batigo, and the last one is $\mathrm{KAN}$, so the society of Minangkabau hat known with the proverb adat basandi syarak, syarak basandi kitabullah, so the value of Restorative Justice can be applied in settling light crime case.
\end{abstract}

Keywords: Restorative Justice, Violence, Women, Children

\section{Introduction}

Restorative Justice is a popular talk all over the world including Indonesia, in the middle of society's dissatisfaction of formal law that dominates by positivism thought and not optimal enough to accommodate people's feelings of justice. Restorative Justice opens a new awareness that settling problems between sides in criminal cases is not only done by revenge but with a peaceful way of discussion, so both sides have an advantage from the decisions that have been agreed together to create a balance between the perpetrator and the victim. The coming and spreading of application about Restorative Justice's values is an inherent criticism of conventional legal court that have not met people's sense of justice. Restorative Justice approach assumed as the best movement from many models and mechanism that works in the Criminal Court System for handling such criminal case nowadays.

In West Sumatra, particularly based on data from the West Sumatra Women's Empowerment and Family Planning Agency for the period of January to September 2016, there were 627 cases of violence against women and children in 19 districts / cities in West Sumatera, consisting of 313 cases of women and 156 against children related to physical 
violence. Women and 111 cases in children related to psychological violence, 35 cases in women and 246 cases in children related to sexual cases, 45 cases in women, 13 cases in children related to neglect and 1 case of trafficking. This concern is reasonable given that children are young people who are expected to have an adequate quality of resources as heirs of the future of the nation.

In a family or kinship system In West Sumatra where most of the population follows the matrilineal family system adopted by the Minangkabau Community, women are the determinants and successors to determine the lineage. Minangkabau kinship is bound by one tribe drawn from a female lineage (sesuku). In addition, women are inheritors of inheritance, especially high inheritance in the Minangkabau community. According to Adat Minangkabau, for example, women are called "Bundo Kanduang" which means biological mothers who have to protect their children and are respected by their children.

The question arises whether this Restorative Justice is new or already in the Indonesian legal system? If we look at the laws in Indonesia, Restorative Justice can be found in Law Number 11 of 2012 concerning the Criminal Justice System of Children and also restorative justice is not different from the settlement of customary offenses in indigenous law communities in Indonesia.

\section{Restorative Justice}

The restorative justice process can be carried out in several mechanisms depending on the existing conditions and even some that combine one mechanism with another, according to Stephenson Giller and Brown there are 4 (four) forms of Restorative Justice [2], namely:

1. Victim Offender Mediation, a form of restorative justice approach that forms a forum that encourages meetings between parties, namely victims and perpetrators and third parties (mediators) who are neutral and impartial, who help the parties to communicate one another with the hope reach an agreement. During the meeting, the victim could describe his experience in connection with the crime he experienced and the effect it caused. The perpetrator explains what criminal acts and background why the perpetrator did this. While the mediator is in charge of providing input for achieving the best possible solution, mediation can be done directly or indirectly.

2. Restorative conference (Conferencing), the form of settlement with this model is an application of restorative justice developed by the Maori tribe, but the implementation of many countries uses this application. In the form of conferencing, the settlement does not only involve the perpetrator and victim directly (primary victim) but also involves the perpetrator and the victim not directly (secondary victim), such as family, close friends of the victim and relatives of the perpetrator.

3. Family Group Conference (FGC), this model is an extension of the conferencing model. This model is used in the handling of criminal acts that perpetrators are children. The focus on completing this model attempts to provide lessons or education for the perpetrator or what he has done. Where both parties (victims and perpetrators) make an Action Plan derived from information from victims, perpetrators and professionals. This is done with the aim of prevention so that an error does not recur.

4. Community Panels Meetings, meetings attended by community leaders, perpetrators, victims and parents of the perpetrators to reach an agreement to correct errors 


\section{Customary Offenses Arrangement in Minangkabau}

In Minangkabau, the regulation on customary offenses is regulated in Law twenty which is a law that regulates criminal law issues, concerning various forms of crimes with certain sanctions, and evidence of a crime and the method of proving it. This law of twenty is essentially composed by the two Minangkabau jurists, Datuk Ketumanggungan and Datuk Perpati Nan Sabatang. This law is divided into two parts, namely :

\section{Undang nan salapan (cemo bakaadaan)}

2.Undang-undang nan duo bale (tuduh nan bakatunggangan)

The salapan law consists of eight articles which state the type of crime each article contains two kinds of crimes which are of the same nature but of different levels, namely:

1. Tikam bunuh, stabbing an action that hurts a person or animal but does not cause the person or animal to die.

2. Upeh racun, an act that causes a person to suffer from pain after swallowing food or drinks that are given a venomous concoction.

3. Samun saka, which means robbing someone else with violence or persecution that causes the person to die.

4. Siar baka, the act of making a fire that causes someone else's property to burn

5. Maliang curi, meaning that it takes the property of others by destroying its storage bag.

6. Dago dagi, the act of violating an order with no right reason to make a rage

7. Kicuah kicang, cheating means fraud and chirping means fraud.

8. Sumbang salah means, acts of adultery for women that should not be married or wrong deeds viewed by the eye, wrong means adultery with the wife of a person, deeds that violate morality.

Minangkabau culture has customs, while customs are based on the teachings of Islam. Such a view of life is contained in the customary philosophy that says; Adat Basandi Syarak, Syarak Basandi Kitabullah. Thus all aspects of the life of Minangkabau people always refer to Minangkabau customs, and at the highest level are based on the teachings of Islam. In the culture of Minangkabau people who adhere to the matrilineal family system of women have an important role and are very attached to the offspring drawn through the maternal line [3].

The existence of customary law, in the Indonesian legal system already has a constitutional basis in Article 18 paragraph (2) of the Basic Law of the Republic of Indonesia and is confirmed in the form of regional autonomy. The existence of the customary law according to Satjipto Rahardjo did not think about or consider whether it was recognized or not by the state's authority, but rather emerged, and was present from the content of the community itself autonomously so that it was called authentic. The position of customary law by Hart is called the "primary rule of obligation", while state law is referred to as "secondary rules of obligation". Such a view shows the urgency of customary law and the values contained in it in the lives of its people including in protecting women and children. Although normatively there are restrictions, restrictions on the implementation of customary law, what is referred to as subject centric or asymmetric and monologic paradigm, such as sepanjang in line with the principle of a unitary state, but with optimization can eliminate limitations [5].

Cultural, traditional and religious values that actually become the characteristics and characteristics of the Minangkabau community. In the community, there is a saying that reminds the roots of society to be aware of various changes. The saying of sakali aia gadang sakali tapian barubah has always been reminded to be careful of changes and always to be able to read and predict the symptoms. The conditions that exist in society must be anticipated, 
because it has been reminded by the saying of cewang di laut tando ka paneh gabak di hulu tando ka hujan. But because customary law was born in the middle of the community, he would tend to adjust to developments in accordance with his flexible nature easily [6].

\section{The Implementation of Restorative Justice in Resolving Violence on Women and Children as a form of Right of origin in West Sumatera}

The concept of Indonesian customary law as a forum for customary justice institutions also has a concept that can be described as the root of restorative justice. In Indonesia, the characteristics of customary law in each region generally strongly support the application of restorative justice. In connection with customary violations or customary offenses, and the mechanism for solving them, customary law has its own views. As noted above, the notion of customary violations is related to the condition of the imbalance of the cosmos in society. In the framework of a restorative justice approach, states that the values rooted by restorative justice are rooted in traditional values in traditional societies such as the value of balance, harmonization and peace in society. Therefore, in some regions it is noted that the customary justice institution is retained as a means for the community to resolve disputes or problems they experience, including criminal cases. Before knowing the value of restorative justice in resolving acts of violence against women and children, it should be known the principles of customary law

The punishment according to adat is not a body punishment but a "soul" punishment. Hina is an unbearable punishment by the souls of the Minang people, as the traditional saying goes "nan sakik kato nan malu tampak" Minang people cannot stand being hit by "kato" instead of hurts more as said "konai". As for those who have the right to unite punishment on someone in sequence are their own people, village, and tribe because that person is a member. If someone's crime is committed within their people, other people have no right to mix it even though the crime is severe. But his people have no right to impose a sentence "to remove" that person from the customs of his country but they may "ostracize" not bringing a sehilir semudik ringan tidak sejinjing berat tidak sepikul, the other party is obliged to support the punishment. his people. Therefore, if someone commits a crime against another person who is not a member of his community who deserves to be punished by the people of his village or tribe, the perpetrator of the village or tribe is the one who punishes the perpetrator. In the custom it is stated "ba abu bajontiek kumua basosa" a small mistake can be exhausted with forgiveness and forgiveness. The perpetrators of crimes that cannot be forgiven anymore because of defiance or have repeatedly been sentenced to be confined outside. The density of the Penghulu as an adat court if necessary, has the authority to "throw" children of nephews who are found guilty according to customary law. Throw away the meaning of getting rid of the indigenous people or not being carried away or sehilir semudik. "Janjang dinaiakan" means that tibo is dikarajo baiek indak bahimbauan, tibo dikarajo barek indak bahimbauan, bad or good happens, whether in the village, tribe or in the nagari is no longer notified. The process of removing these storied beginnings from the village or tribe and if necessary removed from the nagari.

The study was conducted in 7 (seven) nagari consisting of 2 (two) nagari in Luhak Nan Tuo, 2 (two) nagari in Luhak Lima Puluh Kota and 1 (one) nagari in Luhak Agam and 2 (two) nagari in Solok Regency namely :

a. Lintau Buo Sub-District, Nagari Tigo Jangko 


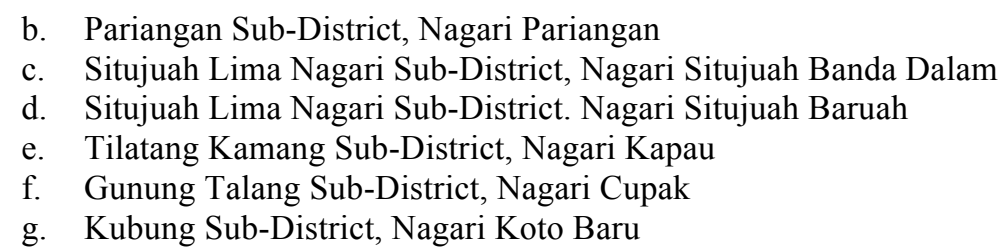

\subsection{Nagari Tigo Jangko}

Consisting of 6 (six) jorong is one of the nagari included in the Lintau Buo sub-district, Tanah Datar District and is one of the nagari in Luhak Nan Tuo / Luhak Tanah Datar. From the results of the interview with Wali Nagari of Tigo Jangko, Mari Yossefli and Chairperson of Kerapatan Adat Nagari stated that the settlement of minor criminal offenses especially violence against women / domestic violence and violence against children was resolved by empowering customary justice in accordance with the principle of deliberation, if it was not reached consensus then the victim would be biased will proceed to State law / court [7]. A uniqueness encountered in Nagari Tigo Jangko in enforcing security and the application of witnesses to violations of customary rules and criminal acts was established in Penjara Nagari. A temporary custom before the case is transferred to the Police or Indigenous Population of Nagari. The Penjara Nagari / Adat is already regulated in the nagari regulations.

\subsection{Nagari Situjuah Batua}

Nagari Situjuah Batua is located in Situjuah Limo Nagari sub-district, Limo Puluh Kota district consisting of 6 jorong. The only nagari in the Limo Puluh Kota district which has produced 6 (six) regulations with the nuances of Islamic law, with the aim of preventing acts of violence against women children and other community diseases. According to the customary leader of Situjuah Batua MKH, Dt Majo Kayo, the six rules agreed upon were niniak mamak, supported by the ulama, cadiak pandai, bundo kanduang, anak mudo and nagari government. if the regulation is violated by the nagari people indiscriminately, will get sanctions or fines even to the point of being sanctioned discarded as long as the custom. The six regulations include [8]:

1.Every people of Nagari Situjuah Batua who is in crowded places is obliged to close the aurat, ninik mamak as the head of the people must wear Muslim clothes and wear a cap.

2.Each people of Nagari Situjuah Batua, is also required to say prayers and read the Koran every night, stay away from immorality if the violation will be prepared by the dubalang and the paga nagari to watch over him.

3.The people of Nagari Situjuah Batua are prohibited from holding various forms of games that smell like gambling, card games, Koa cards, dominoes, starting from Thursday afternoon to Friday night every week. With the existence of these regulations can prevent the nagari of Situjuah Batua community from the disease of the community in general and in particular can prevent violence against women and children. From the results of the study, the interview with Mr. Delferi, the Wali Nagari of Nagari Situjuah Batua, stated that in the village of Situjuah Batua, it was also in the form of an institution/body that handled adat and syara ', namely BP3AS (Customary and Syarian Settlement Investigation Agency) involving the Kerapatan Adat Nagari and Walinagari. This has illustrated that the settlement with restorative justice is applied.

Nagari Situjuah Banda Dalam consists of 8 jorong located in Situjuah Limo Nagari Subdistrict, Limo Puluh Kota Regency In accordance with the saying Minang: elok tapian dek 
nan mudo elok nagari dek pengulu, therefore the importance of the role of ninik mamak in the Minangkabau customary environment in particular and in general, so that ninik mamak must understand the customary order in Minangkabau which has sacred ancestral values.

\subsection{Nagari Situjuah Banda Dalam}

Nagari Situjuah Banda Dalam consists of 8 jorong located in Situjuah Limo Nagari Subdistrict, Limo Puluh Kota Regency In accordance with the saying Minang: elok tapian dek nan mudo elok nagari dek pengulu, therefore the importance of the role of ninik mamak in the Minangkabau customary environment in particular and in general, so that ninik mamak must understand the customary order in Minangkabau which has sacred ancestral values.

\subsection{Nagari Kapau}

Kapau is one of the nagari found in the district of Tilatang Kamang, Agam regency consisting of 12 jorong, using the custom of Koto Piliang with the traditional leader Datuk Katumanggungan with its multilevel customs. Completion of customary offenses / minor criminal acts of nagari kapau batangga naiak batangga turun, that is, resolved in a "paruik" first, then in a "sainduak", the last one is "bainduak" and if it has not reached an agreement then the settlement is submitted to the Kerapatan Adat Niniak Mamak Anam Suku. In the custom of the Anam Suku "basuku bainduak babuah paruik, kampuang dibari banan tuo, rumah dibari batungganai, the panghulu nan anam suku, that is what will be the highest judge in the nagari or according to adat mamacik arek, manggangam taguah. Penghulu nan anam suku are given pulo bapituo, kalau tumbuah according to the custom of Dt Bandaro. Kalau tumbuahin syarak Dt Mangkudun.. Kaduonyo digadangkan according to adat with kato mufakat [9]. Based on the results of the nagari's research in completing minor crimes resolved by deliberation and consensus

\section{Mediation in the Application of Restorative Justice Values in the Settling of Violence Against Women and Children as a Realization of the Right of Origin in West Sumatra}

Adat Minangkabau is a regulation and law or customary law that applies in the social life of Minangkabau people, especially those who live in Ranah Minang or West Sumatra. Within certain limits, Adat Minangkabau is also used and applies to Minang people who are overseas outside the Minangkabau region. Adat is the basis for the power of the Rajo or Penghulu (indigenous community leaders), and is used in carrying out the leadership of indigenous people everyday. All laws and regulations are called Adat, and the foundation is a tradition inherited from generation to generation and by the Islamic Shari'a that has been adopted by the Minangkabau people. Although the research conducted revealed that acts of violence against women and children did not occur frequently in the nagari which was designated as a research location. However, if violence occurs, the nagari as an area that has a legal rule that lives alone has a settlement mechanism.

From the research, it was revealed that the resolution of cases that occurred was more determined based on the forms of violence against women and children that occurred. First, if acts of violence that occur against women and children are classified as serious crimes, such as those that result in death, then the case will be directly handled by state law in this case the police. Against cases like this will usually be directly handled by the police so that the 
community, in this case, the nagari cannot make any efforts. But if the crime is not straightforward and severe, then the solution is usually done in a traditional way that every problem must be resolved by the saying that says: "Ndak ado kusuik nan dak kasalasai, ndak ado karuah nan indak ka janiah".

In addition to resolving cases by paying attention to the severity of acts of violence against women and children carried out, the settlement is also associated with a multilevel settlement mechanism, namely from the level of the closest family, people, tribe, jorong and finally the nagari. This means that if the dispute cannot be resolved through a lower level settlement, a higher level will be taken, namely the level of the headman in Nagari, namely through KAN. Completion in principle is carried out in consultation and consensus to seek peace. This was revealed in the saying that said: "Bulek aia dek pambuluah, bulek kato dek mufakat". When an agreement has been reached, the parties must obey and carry out the agreement properly. This was expressed by the saying: "Kok bulek lah bisa digolongkan dan kok picak lah bisa dilayangkan."

In the settlement, it is always followed by both parties and other parties consisting of ninik mamak, customary leaders, as well as jorong and nagari apparatus. In cases that are not too severe, it can also be done by involving law enforcement officers who are governmentformed institutions at the nagari level, namely through the Forum Kemitraan Polisi dan Masyarakat. This institution in addition to striving to do prevention in certain stages strives to settle cases of minor crimes and seek settlement in a family and peace manner. The informal settlement of cases carried out at all levels in addition to trying to find a trial can be followed by giving sanctions to parties who bring disputes. The issuance of sanctions is basically not physical but rather is aimed at sanctions that are social in nature and provide compensation. The provision of social sanctions is in the form of mild to severe, which is to dibuang sapanjang adaik dan dibuang sapanjang nagari (dispose as long as the custom and dispose of the nagari). The granting of compensation payments to the victim or the community is aimed more at restoring balance which has been disturbed by an act of violation. The sanction of dispose as long as the custom or dispose of the Nagari is revealed from the saying which says: "kok duduk ndak dibao barunding, kok tagak ndak dibao bajalan". Whereas the sanction of disposal from the Nagari was revealed by a pantun stating: Bukik Putuih Rimbo Kaluang, tampek urang marandang kopi. Kato putuih badan tabuang, dipandang kampuang ditangisi. Payment of compensation as a form of sanction is intended to correct the damage or loss suffered by the victim. This is owed in the saying that: "kok bangkak didamak kok luko ditaweh." While sanctions aimed at the general public are usually by paying by custom or by performing traditional ceremonies which are expressed in the following words: Adat diisi timbago dituang. Customary fines are usually used for general trouble such as building roads, bridges or certain buildings that are used together and to restore the balance of adat and the people who have been disturbed by an act. compensation for the victim or the community which is aimed more at the recovery of balance which has been disturbed by an act of violation. The sanction is to throw away as long as the custom or dispose of the Nagari is revealed from the saying which says: "kok duduak ndak dibao barundiang, kok tagak ndak dibao bajalan". Whereas the sanction of discarding the Nagari was revealed by a pantun stating: Bukik putuih rimbo kaluang, tampek urang marandang kopi. Kato putuih badan tabuang, dipandang kampuang ditangisi. Payment of compensation as a form of sanction is intended to correct the damage or loss suffered by the victim. This is owed in the saying that: "kok bangkak didamak kok luko ditaweh." While sanctions aimed at the general public are usually by paying by custom or by performing traditional ceremonies which are expressed in the following words: Adaik diisi timbago dituang. Customary fines are usually used for 
general problem such as building roads, bridges or certain buildings that are used together and to restore the balance of adat and the people who have been disturbed by the violation.Every decision that is given in various levels of dispute resolution that exists must be done fairly and with awareness. The implementation of the joint decision was stated in the expression: "Kok bulek lah bisa digolongkan kok picak lah bisa dilayangkan." It was stated in the expression: Kok tibo dimato indak dipicingkan kok tibo diparuik indak dikampihan. So all parties must support the realization. With the completion of the customary decision, all will return to the original state, no other parties who object or take other actions beyond the accords already obtained. If there is still an action beyond the existing agreement, the case will be handed over to the authorities through the completion of criminal law enforcement. The community, in this case both the government of the jorong, the nagari or theupu ninik mamak and the headman are no longer responsible for the actions carried out so the concerned will bear their own risk. This was stated in the statement saying: "Sia malompek sia patah sia manyuruak sia bungkuak." The expression will mean that indigenous peoples are free from all responsibilities carried out by the person concerned.

From the results of research carried out on 7 (seven) Nagari in West Sumatra shows the process of customary justice in Minangkabau is still recognized and continues to run, in his dissertation Eva Achyani Zulfa said the concept of customary law and customary justice is the root of restorative justice found in customary law such as:

1. Religious style, which places customary law as a form of the inner unity of society in one unit.

2. The communal nature of customary law places the individual as a person who is bound by society, an individual is not a free person in every practice, because he is limited by the norms that apply to him.

3. The purpose of community partnership is to maintain the balance of physical and soul bond between individuals or groups.

4. The purpose of maintaining a balance physical and soul bond stems from the view of the order of the universe (cosmos). Community interest is the relationship between everything in accordance with the line and the balance of the cosmos.

5. Violation of customary law is a violation of cosmic order.

6. If the cosmic line is not lived even though by an individual, both the community and the person will suffer because they are outside the existing cosmic line.

From the research conducted on 7 (seven) Nagari in West Sumatra it was revealed that there were several principles for resolving disputes or customary cases, including:

1. The principle of internal settlement first. This principle basically wants every case to occur in advance by the parties concerned ( indak mancari angok kalua badan ).This principle aims to achieve agreement between the two parties and not to cause worse things, especially the honor of the parties ( bak manapuak aia di dulang, bak mancabia baju di dado ) means an act that will bring harm or shame to myself. This principle basically provides more justice for both ( win-win solutions ), but for the problem of sexual violence against women and children certainly cannot done for all forms of violence and it is not always easy to find agreement between the two parties.

2. The principle of consensus deliberation. Every settlement of disputes according to Minangkabau customary law is always aimed at the consensus deliberation process. Deliberation and consensus are aimed at achieving peace for both parties. Thus the decision is always aimed at the interests of the two parties. With deliberation and consensus, the results achieved will pay attention to the common interests not only 
the interests of one party. The mechanism of consensus deliberation is reflected in the saying: "Bulek aia dek pambuluah, bulek kato dek mufakat."

3. Multilevel Settlement Principles. Settlement of disputes takes place at a stage or level in accordance with the composition of the nagari society as stated in the saying "bajanjang naiak batanggo turun" reflects the principle of porosity that everything must be in accordance with the urgency and need. The community has a settlement mechanism from the lowest level to the higher level. First: the level of the people by the density of the clan and tribe by tribal density, the pattern of settlement is mediating or reconciling., Second; at the level of nagari the settlement is carried out if there has been devolution from the tribal leader as functionary for the settlement of mamak disputes to the heirs. From the research it was revealed that most of the cases could be resolved at a lower level. Rarely is a case taken to a higher level of resolution. Considering that the decision is obtained through deliberation and consensus, the results obtained are more acceptable to both parties, this is in line with being obtained through consensus and consensus, the results obtained are more acceptable to both parties.

4. Principle of justice. The principle of justice is one of the main principles in Minangkabau customary law, especially in solving each problem. Even in the customary expression it was stated that: "Rajo adia Rajo disambah Rajo, rajo zalim rajo disanggah". This means that fair leaders must be respected and adhered to if they do not have to be straightened out or criticized. In customary justice the principle is reflected in the expression which says: "Maukua samo panjangmanimbang samo barek". With the settlement process, every case must pay attention to the principle of justice. Even though the expression is explicitly quantitative, it must also pay attention to qualitative, which means not only the interests of the parties as well as the interests of society.

Although basically in the communities in the nagari still exist and live the customary law is included in matters relating to how to provide protection for women and children from sexual violence, as well as in the resolution of cases relating to violence against women and children, but specifically in its development and its completion, formal elements have been entered and applied, namely from the government and law enforcement officials. If a case occurs, it cannot be resolved internally, then a settlement must first be made with the involvement of government officials such as: Wali Nagari and cops. Institutions like that have actually been formalized at the nagari level through the institution of the Forum Komunikasi Polisi Masyarakat (FKPM) and Babhinkatibmas, this institution exists in each village consisting of elements of the KAN nagari government, ninik-mamak and cadiak pandai and police assigned to the nagari through Bhayangkara Pembina Ketertiban dan Keamanan Masyarakat (Bhabinkamtimbas). Through this forum measures are taken to make peace and if Bhabinkamtibmas also cannot complete then a police report is made. In many ways these institutions are very useful and play a role in resolving various cases and problems that are no longer resolved internally.

\section{Conclusion}

Finally, it can be concluded that one of the advantages and privileges of restorative justice is the way to resolve cases / disputes can be adjusted to the local wisdom procedures known 
by the community or local community. In Minangkabau the imposition of sanctions was decided after weighing both good and bad by ninik mamak, imam, cadiak pandai who presented communal unity in the nagari. occurs after the incident, restorative justice puts communication as an important part in the Minangkabau customary justice models.

\section{References}

[1] Yaswirman. 2011. Hukum Keluarga, Karakteristik dan Prospek Doktrin Islam dan Adat Dalam Masyarakat Metrilineal Minangkabau, PT Raaja Grafindo Persada: Jakarta.

[2] Iswara, I Made agus Mahendra. 2013. Mediasi Penal,Penerpan Nilai-Nilai Restoratif Justiced Dalam Penyelesaian Tindak Pidana Adat Bali. Thesis: UI Jakarta.

[3] Irawati, and Kusdarini, Peluang dan tantangan bagi Peran Politik Perempuan dalam Badan Perwakalan Anak nagari (BPAN), in Ziyardam Zuber (ed). 2010. Adat, Islam dan Gender, Pergulatan dalam Merumuskan Identitas Diri, Lembaga Penelitan Universitas Andalas.

[4] Rahardjo, Satjiopto. 2005. Hukum Adat dalam Negara Kesatuan Republik Indonesia (Perspektif Sosiologi Hukum), in Komnas HAM, Masyarakat Hukum Adat,Inventarisasi dan Perlindungan Hak. Komnas HAM: Jakarta

[5] Hardiman, F. Budi. The Structural Position of the Etnic Group, and the relaltionship between Ethnic Groups in the Nation and State Life in Indonesia, in Indonesia Ignas Tri (ed) National Commission on Human Rights, Indegeneous Peoples, The Structural Relationship Among Tribal Groups, Nation and the State. 2006. Komnas HAM: Jakarta

[6] Mulyadi, Yanis. Eksistensi Hukum Adat dalam Konstitusi Negara Pasca Amendemen UUD 1945. Law and Development Journal, 41 (3) p. 437

[7] Interview from Mari Yosefi Walinagari Tigo Jangko on Monday October, 32017 at 11.00 A.M

[8] Interview from Delferi Walinagari Situjuah Batua on Monday October, 162017 at 10.00 A.M

[9] Interview form Zulkarnain Walinagari Kapau on Monday October, 162017 at 02.00 P.M 